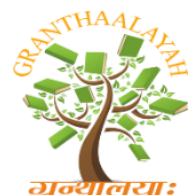

Social

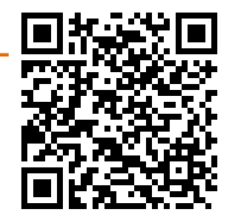

\title{
LINKAGE BETWEEN INCOME DIVERSIFICATION AND ASSET OWNERSHIP IN RURAL HOUSEHOLDS OF YAYU WOREDA AND HURUMU WOREDA, OROMIA REGIONAL STATE, ETHIOPIA
}

\author{
Mabiratu Dangia Kajela ${ }^{1}$, D. Prem Kumar Dara ${ }^{1}$ \\ ${ }^{1}$ Gambella University, Gambella, Ethiopia
}

\begin{abstract}
Rural households are engage in a variety of farm and non-farm activities based on initial assets endowments to diversify their income and cope with the risk of agricultural loss. This study was designed to assess linkage between income diversification and asset ownership among rural households in study area. Mult-stage sampling techniques were used to collect primary data from 237 farm households using semi-structured questionnaire. Descriptive statistics and econometric models were used to analyze the data. Tobit model was used to pinpoint factors that affect intensity of household income diversification and principal component analysis was used to index asset owned by households. The study shows that farm activities are the most important source of income for rural households in the study area contributing $90.92 \%$ of total households income with the remaining $9.08 \%$ originating from non-farm activities. A mean of income diversification index is $0.414(41.4 \%)$. Factors that affect intensity of household income diversification were: aggregate index of human capital, aggregate financial capital index and extension contact positively and membership in agricultural cooperative, sex of household heads and access to training negatively. In the study area generally, household asset ownership positively and significantly affected intensity of households income diversification and it has served as means for income diversification. Asset endowment needs to be considered by policy makers in the planning of agricultural and non-agricultural initiatives in the study area.
\end{abstract}

Keywords: Asset Ownership; Income Diversification; PCA; Tobit model.

Cite This Article: Mabiratu Dangia Kajela, and D. Prem Kumar Dara. (2019). "LINKAGE BETWEEN INCOME DIVERSIFICATION AND ASSET OWNERSHIP IN RURAL HOUSEHOLDS OF YAYU WOREDA AND HURUMU WOREDA, OROMIA REGIONAL STATE, ETHIOPIA." International Journal of Research - Granthaalayah, 7(1), 56-72. https://doi.org/10.29121/granthaalayah.v7.i1.2019.1035.

\section{Introduction}

Sustainable livelihoods approach is concerned first and foremost with people. It seeks to gain an accurate and realistic understanding of people's strengths (assets or capital endowments) and how they endeavor to convert strengths into positive livelihood outcomes [1]. Income diversification is 
increasing the range of income generating activities outside farm operations by allocating existing household resource to such activities [2]. Rural households expand income generating activities in order to increase income and to cope fluctuating income and cover consumption cost of the household.

Studies on the importance of income diversification justify that it has positive link with accumulation of household assets and in the time of exogenous shocks such as droughts and floods income diversification gives the household the capability of withstanding these exogenous shocks [3]. Besides contributing to the total family income of the rural household, in the long run income diversification leads to structural shift in rural employment away from agricultural sector to the industrial sector [4].

In developing country majority of populations live in rural areas are depending on agriculture to sustain their livelihood. Agriculture is the dominant economic activity for most of rural households living in Sub-Saharan Africa. And agriculture give more option for households to expand their income, to overcome food insecurity and overcome poverty [5].

Concept of sustainable livelihoods is deals with people and improving households life standard. Sustainable livelihood seeks to gain power of people to convert assets or capital endowed into positive livelihood outcomes [6]. Income diversification deals with increasing the range of households income generating activities outside farm operations by allocating existing household resources to such activities [7].

Barrett and Reardon, [8] define asset as: "Assets are stock of directly or indirectly productive factors that produce a stream of cash or in-kind returns (or what economic theorists typically call endowments)". According to these authors individual assets are categorized in to productive or nonproductive assets. Productive assets are those utilized during production process such as financial capital, fixed capital, human capital and nonproductive ones include those that generate income through remittance or transfers such as social net work and social claims.

Expansion of agriculture employment in Ethiopia is become difficult, because of increasing rate of population growth and declining of households land ownership [9].

Hoogeveen [10] stated that, poor households who own less asset stock and less access to financial institution are highly limited to access to most rewarding income sources because of the entry barriers. Richer households who own more capital assets have greater opportunity to engage in wider range of non-farm and farm activities than the poor.

Household capital assets help them to increase total production, to increase household income and to keep their family from food insecurity during off-season of production. Asset and income diversification contribute in smoothing consumption, risk coping and creating job opportunity for family members. Transformation of asset into household livelihood are not well recognized in empirical results, rather it was recognized in the more theoretical economics and agricultural economics literature. 
Some study considered income diversification as share of off-farm income or intensification of agricultural activities $[11,12,13]$. This approach has some shortcoming, including the fact that it does not account for heterogeneity in the off-farm income sources.

Previous studies more concentrated on importance of income diversification and function of assets in smoothing consumption of households. But in this study We have discussed, existing households income sources and their shares in households total income, linkage between rural households income diversification and asset ownership, and determinants of rural households intensity of income diversification in the study area.

Limitations faced the author during study was absence of related study on the linkage between asset ownership and income diversification.

\subsection{Research Questions}

1) What are the existing income sources of households and their share in total $\mathrm{HH}$ income in the study area?

2) What is the linkage between households intensity of income diversification and assets owned by households in study area?

3) What are the determinants of household's intensity of income diversification?

\subsection{Objectives}

\section{General Objectives}

- To assess linkage between rural households income diversification and asset ownership in Yayu Woreda and Hurumu Woreda.

\section{Specific Objectives}

- To asses existing household income sources and their shares in households total income in the study area.

- To examine linkage between rural households income diversification and asset ownership in study area.

- To analyze determinants of rural households intensity of income diversification in study area.

\subsection{Significance of the Study}

This study is significant for it contribute both in terms of conceptual understanding regarding the livelihood income and diversification in the rural households through adding an input to the existing literature pool on the issue. In addition, it has also a practical contribution by which the understanding of livelihood activities of the rural households would help to solve various problems such as food in security, environmental degradation and the factors affecting the activities of the rural households. Thus, the study will support the efforts of policy makers, development planners, local authorities and other governmental or non-governmental organizations by providing information on linkage between asset ownership and income that are employed by rural households in the study area. 


\subsection{Scope of the Study}

This study was restricted to Yayu and Hurumu woreda. There could be a lot of variables that are related to the livelihood strategies and the process of diversification and analyzed in different ways. However, this study is focused on assessing the type of income sources, effect of asset owned on the intensity of income diversification and identifying the determinant factors to the process of income diversification. Therefore, the scope of the study were limited and focused in its coverage to the subject matter, so that it would produce knowledge and understanding on the subject of the study.

\subsection{Conceptual Framework}

DFID adopts livelihood framework Chambers and Conway definition of a livelihood. Define livelihood as;" livelihood comprises the capabilities, assets and activities required for a means of living. A livelihood is sustainable when it can cope with and recover from stresses and shocks and maintain or enhance its capabilities and assets both now and in the future, while not undermining the natural resource base'".

DFID lack explanation of importance of capital assets, less focus of livelihood outcome and they categorize asset into five basic capitals. Those are natural capital, social capital, physical capital, human capital and financial capital

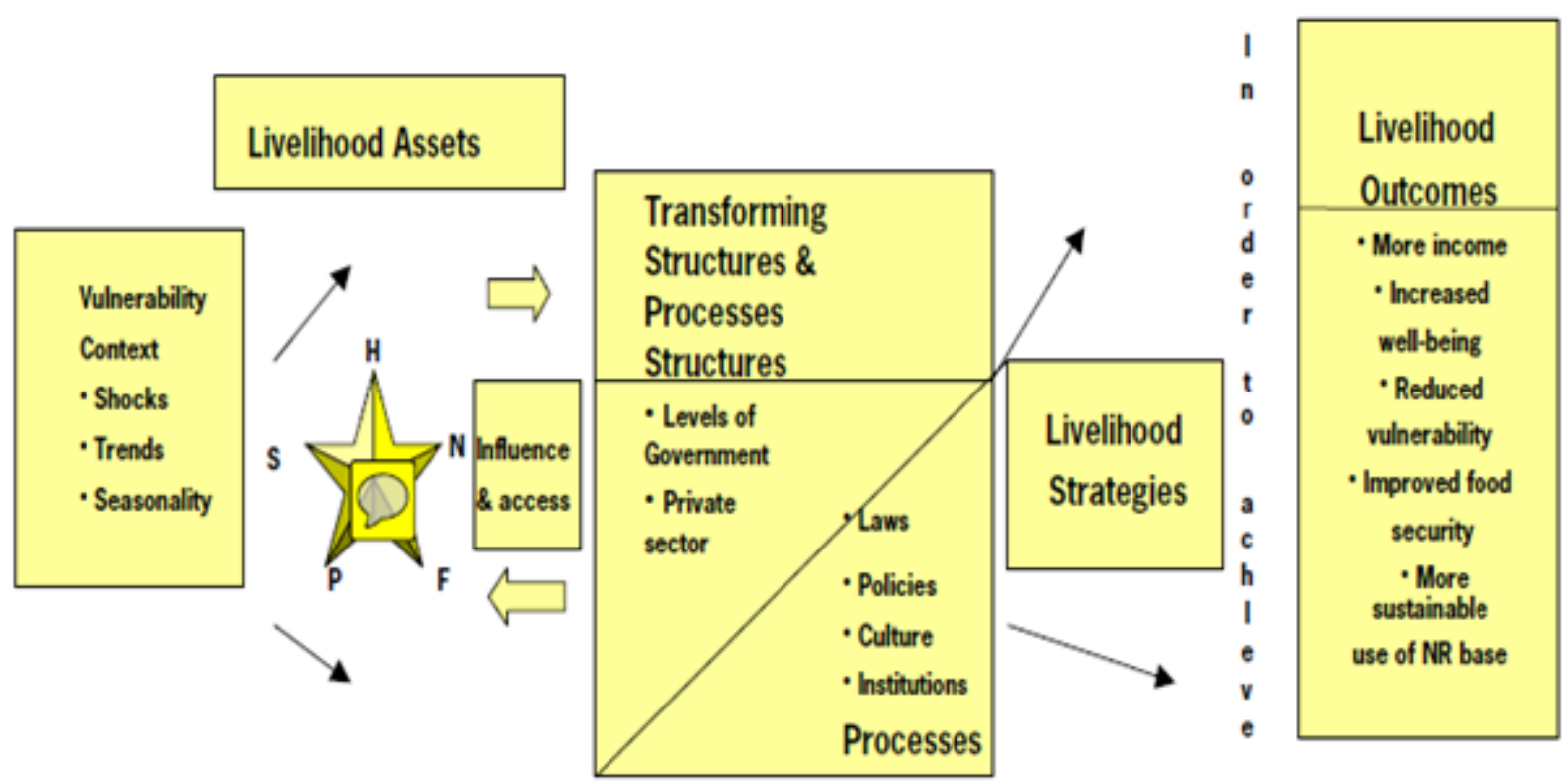

Figure 1: Sustainable livelihood framework

Source: drawn based on DFID sustainable livelihood framework [14].<smiles>[TeH2][Pb]1CCCCC1</smiles>

H=human capital: any things that contribute to capacity of human to perform different livelihood activities.

$\mathbf{P}=$ physical capital: is physical assets and capital used as factor of production and which enable to undertake any livelihood activities. 
$\mathbf{S}=$ social capital: is basic social resource which help rural household to pursue any livelihood activities.

$\mathbf{F}=$ financial capital: are any financial resources which people use to engage in different livelihood option

$\mathbf{N}=$ natural capital: is any stocks of resource from which are allocated by nature for people to engage in different livelihood option.

\section{Research Methodology}

\subsection{Description of Study Area}

Yayo and Hurumu woredas' are found in Iluu Abba Bora zone of Oromia Regional State. Iluu Abba Bora is situated in southwestern part of Oromia Regional State as well as the country. It is bounded by East Wellega and Jimma zones in the east. Iluu Abba Bora also shares a border with West and East Wellega in the North; SNNPR in the south, and with Gambella Regional State in the west. The total area of the zone is 1,633156.6 hectares divided into twenty-two districts including Yayo and Hurumu districts (woredas agriculture office).

Towns in Yayu include Elemo and Yayu. The 2007 national census reported a total population for this woreda of 52,851, of whom 26,737 were men and 26,114 were women; 7,557 or $14.3 \%$ of its population were urban dwellers (woredas agriculture office).

The districts have hot and humid climatic condition. The mean annual temperature is about 230c ranging between $18.590 \mathrm{c}$ mean minimum annual temperature and $27.880 \mathrm{c}$ mean maximum temperature (woredas agriculture office).

\subsection{Data Types and Methods of Data Collection}

Data used in this research was cross sectional data that obtained from primary data sources. Both quantitative and quantitative data's were used to undertake this study. Primary data's were collected through structured questioners from 237 respondents that were selected from two woredas. Interview guide was used for the collection of data from selected focus group discussion that were held with Kebeles administrator, development agent workers, model farmers and other kebele administrator workers. Secondary data's were collected from published and unpublished journals, books and theses, and agricultural reports and rural development office of the study area.

\subsection{Sampling Techniques and Sample Size Determination}

Combination of random sampling and stratified sampling methods were used to select sample respondents. Studied woredas were stratified as highland and lowland kebeles. Among the eleven kebeles found in the yayu woreda, five were in lowland and six were in highland. Similarly, among the eight kebeles found in the hurumu woredas, four were in highland and four were in lowlands. In the first stage two sample kebeles were selected randomly from each stratum. Accordingly, from yayu woreda, Wabo and bondo megela kebeles were randomly selected from highland and lowland, respectively. Similarly, from hurumu woreda, Gaba and wangenye kebeles were randomly selected from highland and lowland, respectively. At the second stage, probability 
proportional to sample size was used to select 237 respondents randomly from the four selected kebeles for interview. The sample size for this study was determined using Yemane [15], sample size determination formula as;

Where:

$\mathrm{N}=$ is sample frame of woredas (6372),

$\mathrm{N}=$ is determined sample size and

$\mathrm{E}=$ is expected error value $(6 \%)$.

\subsection{Model Specification}

\section{Principal Component Analysis}

Principal component analysis was used to compose assets components to asset index. One assets index has at least three assets components. So those, the basic importance of using principal component analysis were to redefine assets components into asset index. Assets index composed by principal component analysis are mutually-orthogonal linear combinations of the original variables.

Empirically specified as follows:

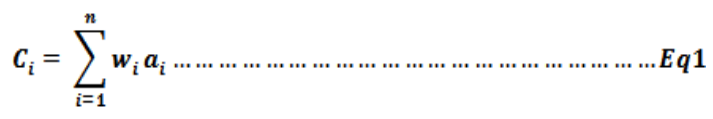

Where;

$\mathrm{Ci}$ =asset index

$\mathrm{Wi}=$ conversion factor determined by principal component analysis for each index components $\mathrm{ai}=$ asset index components

Depending on eigenvalue, conversion factor used for the indexing was estimated. In most cases, the first component used to index components which assign a larger weight to components that vary the across households so that an asset factor found in all households is given a weight of zero [16]. The eigenvector with the highest eigenvalue is the principle component of the data set [17]. For assets type PCA specified as follows:

$$
\begin{aligned}
& Y_{1}=W_{11} E H H+W_{21} H H S+W_{31} T T+W_{41} A G E \\
& Y_{2}=W_{12} T L+W_{22} C L+W_{32} K L \\
& Y_{3}=W_{13} T L S+W_{23} H I+W_{33} D G \\
& Y_{4}=W_{14} A C+W_{24} F F I+W_{34} L S \\
& Y_{5}=W_{15} S L+W_{25} S A+W_{35} T A
\end{aligned}
$$


Where Y1=index of human capital, Y2=index of natural capital, Y3= index of physical capital, Y4=index of financial capital and Y5=index of social capital, and the estimation of relative asset index using PCA was done based on the first principal component.

\section{Estimating the Degree of Income Diversification}

In this study Simpsons Index of Diversity (SID) were used to estimate household level of income diversification. Advantage of using SID is since it takes into account both all components of indexed value and their distribution among each component [18, 19]. The SID ranges between Zero (0) and One (1). Thus, 0 denotes specialization and 1 the extremity of diversification.

$$
S I D=1-\sum_{i=1}^{n} P_{i}^{2}
$$

Where; SID = income diversification

$\mathrm{n}=$ number of income sources,

$\mathrm{Pi}=$ percentage of income come from each income sources.

Income diversification value varies between one and zero. One implies, households' income generated from all income sources and zero indicates households income generated from only one income sources.

\section{Factors Affect Intensity of Income Diversification}

Tobit model was used to analyze factors that affect household income diversification, because dependent variable (income diversification index) is limited dependent variable. Value of income diversification index is varied between zero (0) and one (1). Presence of zero in value of income diversification index indicates that presence censored data which demand tobit model.

As specified by Green, [20], the mode was specified as follows:

$$
\boldsymbol{Y}_{i}^{*}=\beta_{i} X_{i}^{*}+U_{I}
$$

$\mathrm{Yi}=\max \left(0, \mathrm{Y}^{*}\right)$

$\mathrm{Yi}^{*}$ - households income diversification index

$\mathrm{Bi}$ - is tobit coefficient

$\mathrm{Xi}$ - variables affect household income diversification index and

Ui- is stochastic variable

$\mathrm{Yi}=0$ if $\mathrm{Yi}^{*}<0$ and

$\mathrm{Yi}=\mathrm{Yi}^{*}$ if $\mathrm{Yi}^{*}>0$

$\mathrm{SID}=\mathrm{F}$ (Gender $\mathrm{HHH}$, fertilizer use, improved seed use, extension contact, cooperative membership, distance from market, access to irrigation, access to training, human capital, natural capital, physical capital, financial capital, Social leadership) 


\section{Result and Discussions}

\subsection{Household Characteristics}

The results show that the mean age of household head is 42.24 year. The maximum and the minimum age record in is 80 year and 20 year, respectively.

Table 1: Summary of household characteristic

\begin{tabular}{|l|l|l|l|l|}
\hline Variable & Mean & Sta. dev & Minimum & Maximum \\
\hline Age & 42.24 & 14.04 & 20 & 80 \\
\hline Education & 4.35 & 2.35 & 0 & 9 \\
\hline Educated Family & 3.03 & 1.69 & 0 & 6 \\
\hline Household Size & 4.62 & 1.65 & 2 & 10 \\
\hline Total Land & 2.05 & 2.27 & 0 & 20 \\
\hline
\end{tabular}

Source: own survey

The mean household size of the sample households is about 5 persons. The minimum and maximum household size of the sample households is 2 and 10 persons, respectively. The results show that, households' possession of total land ranged from the smallest 0hectar to the highest 20hectar.

\subsection{Income Source Analysis}

\subsubsection{Household Income Source}

As indicated in table 2 below, totally nine household income sources were identified as generated from farm and nonfarm activities. Food crop, cash crop and livestock are the major households income source in the study area and they account for $87.5 \%$ of the total households income. From total sample households, $43 \%$ of the households were involved in various non-farm activities which illustrate the importance of non-farm income among rural households in the study area. The basic reasons of households to engage in non-farm income sources were; to fulfill family needs in terms of food security, cover loan repayment, to cover miscellaneous expenses and to keep their families from environmental risks during off season period.

Even if, agricultural land is declining from time to time, a significant part (57\%) of the sample respondents received total amount of their income from farm activities only. As observed from the survey result, farm activities cover $90.92 \%$ of total household income. As indicated in table 3, households of Yayu and Hurumu Woredas received $93.5 \%$ and $89 \%$ of their income from farm activities, respectively.

Table 2: Household income sources and percentage share.

\begin{tabular}{|l|l|l|l|l|}
\hline Variables & Percentage & Std. Dev. & Min & Max \\
\hline Food crop & 32.21 & .2885726 & 0 & 100 \\
\hline Cash crop & 45.63 & .3079396 & 0 & 100 \\
\hline Natural resource & 0.38 & .0417632 & 0 & 59 \\
\hline Livestock & 9.42 & .1901783 & 0 & 99 \\
\hline
\end{tabular}




\begin{tabular}{|l|l|l|l|l|}
\hline Farm wage & 3.26 & .0911248 & 0 & .5 \\
\hline Non-farm wage & 5.04 & .1243458 & 0 & 82 \\
\hline Self-employment & 2.30 & .1241619 & 0 & 100 \\
\hline Remittance & 0.14 & .0137771 & 0 & 16 \\
\hline Others & 1.57 & .084439 & 0 & 76 \\
\hline Total non-farm & 9.08 & .1849089 & 0 & 100 \\
\hline Total farm & 90.92 & .1849089 & 0 & 100 \\
\hline Total income & 23521.96 & 59143.23 & 1110 & 633000 \\
\hline
\end{tabular}

Source: own survey

The result given in table 3, shows the significant difference exist in total income between the studied woredas at $1 \%(\mathrm{t}=12.58)$ significance level. As indicated in table 3, households of two woredas were received 38,962.2ETB and 12,055.3ETB in Yayu and Hurumu woredas, respectively. The mean total income in study area were 23,521.96ETB (table 2). This difference in income share implies the existence of significant barriers in selection of the most remunerative income source.

Table 3: Income sources of households of two woredas in percent.

\begin{tabular}{|c|c|c|c|c|c|}
\hline \multirow[b]{2}{*}{ Number } & \multirow[b]{2}{*}{ No } & \multicolumn{2}{|c|}{ Woredas } & \multirow[b]{2}{*}{ Mean } & \multirow[b]{2}{*}{ T-value } \\
\hline & & Yayu & Hurumu & & \\
\hline 1 & Farm income percent & 93.46 & 89.02 & 90.92 & $3.37 *$ \\
\hline 2 & Non-farm income percent & 6.53 & 10.97 & 9.08 & $3.37 *$ \\
\hline 3 & Farm income in ETB & 38258.57 & 10996.48 & 22614.50 & $12.96 * * *$ \\
\hline 4 & No-farm income in ETB & 703.57 & 1058.86 & 907.45 & 1.38 \\
\hline 5 & Total income in ETB & 38962.15 & 12055.34 & 23521.96 & $12.58 * * *$ \\
\hline
\end{tabular}

$\mathrm{ETB}=$ Ethiopian Birr

$* * *, * *$, and $*$ indicate significances at $1 \%, 5 \%$ and $10 \%$, respectively.

Source: from my survey

The result shows, presence of significant mean difference among household in non-farm income share between two agro-ecology at $5 \%(\mathrm{p}=0.014)$ of significance level. As indicated in table 4, in lowland and highland households received in average $7.5 \%$ and $11 \%$ of their income from nonfarm activities, respectively. And farm income share is significantly different between the two agro-ecology at $5 \%(\mathrm{p}=0.014)$ significance level, which is in lowland contribute $92.47 \%$ and in highland $88.9 \%$ of total household income.

Table 4: Income sources of households of two agro-ecology

\begin{tabular}{|l|l|l|l|l|}
\hline Income sources & Agro-ecology & Percentage share in total income & Std. Dev. & P-value \\
\hline \multirow{2}{*}{ Food crop } & lowland & 32.74 & 30.41 & $0.075^{*}$ \\
\cline { 2 - 5 } & highland & 31.54 & 26.85 & \\
\hline \multirow{2}{*}{ Cash crop } & lowland & 43.85 & 30.98 & 0.314 \\
\cline { 2 - 5 } & highland & 47.91 & 30.54 & \\
\hline Nivestock & lowland & 11.91 & 21.67 & $0.023^{* *}$ \\
\cline { 2 - 5 } & highland & 6.24 & 14.44 & \\
\hline \multirow{2}{*}{ Natural resource } & lowland & 0.05 & 0.63 & 0.203 \\
\hline
\end{tabular}


DOI: 10.5281/zenodo.2550091

\begin{tabular}{|c|c|c|c|c|}
\hline & highland & 0.79 & 6.25 & \\
\hline \multirow{2}{*}{ Farm wage } & lowland & 3.91 & 10.13 & \multirow[t]{2}{*}{0.215} \\
\hline & highland & 2.42 & 7.58 & \\
\hline \multirow[t]{2}{*}{ Total farm } & lowland & 92.47 & 16.07 & \multirow[t]{2}{*}{$0.014 * *$} \\
\hline & highland & 88.92 & 21.09 & \\
\hline \multirow{2}{*}{ Non-farm wage } & lowland & 4.99 & 11.47 & \multirow[t]{2}{*}{0.948} \\
\hline & highland & 5.10 & 13.62 & \\
\hline \multirow[t]{2}{*}{ Self employment } & lowland & 1.59 & 10.29 & \multirow[t]{2}{*}{0.315} \\
\hline & highland & 3.22 & 14.69 & \\
\hline \multirow[t]{2}{*}{ Total non-farm } & lowland & 7.52 & 16.07 & \multirow[t]{2}{*}{$0.014 * *$} \\
\hline & highland & 11.07 & 21.09 & \\
\hline
\end{tabular}

$* * *, * *$, and $*$ indicate significances at $1 \%, 5 \%$ and $10 \%$, respectively.

Source: from my survey

\subsubsection{Asset Ownership and Income Diversification}

Average households income diversification index in study area is $0.397(39.7 \%)$. At household level high variation in household income diversification index were considered; which is 74.9 percent as a maximum diversification index and 0 as minimum percentage of diversification index. As mentioned asset ownership indexed using conversion factors that were estimated using principal components. In this case first component of principal component was used to convert asset component into asset index. Accordingly, for natural asset and social asset the weight is zero. Because of the common value of social and natural asset for all respondents in study area, conversion factor for each asset components of social and natural capital is zero.

Table 5: Asset composition and components loading

\begin{tabular}{|l|l|l|l|}
\hline Number & Asset type & Measuring indicators & Conversion factor \\
\hline \multirow{3}{*}{1} & \multirow{3}{*}{ Human capital } & Educated family member & 0.6911 \\
\cline { 3 - 4 } & & Education of HHH & 0.7027 \\
\cline { 3 - 4 } & Age of HHH & 0.1611 \\
\cline { 3 - 4 } & Labor security & 0.0504 \\
\hline \multirow{3}{*}{3} & House instance & 0.4285 \\
\cline { 3 - 4 } & \multirow{3}{*}{ Physical capital } & Durable good & 0.5073 \\
\cline { 3 - 4 } & & Bee hive & 0.2898 \\
\cline { 3 - 4 } & Livestock & 0.6893 \\
\hline \multirow{3}{*}{ Financial Capital } & Access to credit & 0.6921 \\
\cline { 3 - 4 } & & Credit received & 0.682 \\
\cline { 3 - 4 } & Labor ability & 0.2365 \\
\hline
\end{tabular}

Source: own survey

Table 5 constructed depends on PCA outcome and it is not constant for asset components. The study revealed that those female headed $\mathrm{HH}$ owned more human capital (12.1) and financial capital (1923) than male household headed (10.99 and 1543.5, respectively) and households headed by females were found to diversify more (47\%) sources of their income than male headed households 
(39.9\%). As indicated on above figures all asset types have positive effect on $\mathrm{HH}$ degree of income diversification.

Average physical assets were not significantly different between lowlands (225) and highlands (328) of studied areas (table 5). Figure 1 indicates how income diversification goes with ownership of physical capital and indicate the positive effect of physical capital ownership on household intensity of income diversification. In this case households whose degree of income diversification is less than mean of studied area were not owned any physical capitals.

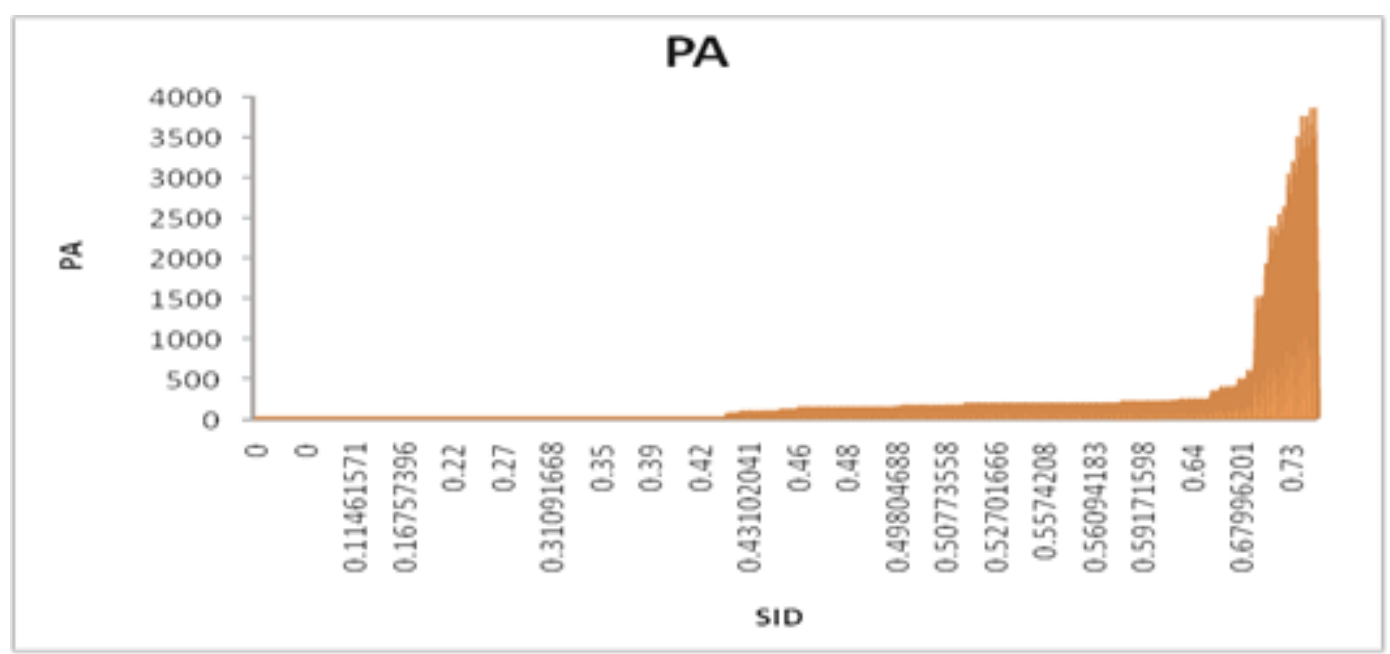

Figure 1: Linkage between physical capital and income diversification $\mathrm{SID}=$ Simpson index of diversification, $\mathrm{PC}=$ Physical Capital Source: own survey

Table 5: Summary of HH asset ownership and mean difference among two agro-ecology

\begin{tabular}{|c|c|c|c|c|}
\hline \multirow[b]{2}{*}{ Asset type } & \multicolumn{3}{|c|}{ Ecology } & \multirow[b]{2}{*}{ P-value } \\
\hline & & Lowland & Highland & \\
\hline \multirow[t]{2}{*}{ Human capital } & Mean & 11.2 & 11.2 & \multirow[t]{2}{*}{0.941} \\
\hline & Std. dev. & 3.9 & 2.1 & \\
\hline \multirow[t]{2}{*}{ Physical capital } & Mean & 225.6 & 328. & \multirow[t]{2}{*}{0.256} \\
\hline & Std. dev. & 590.26 & 793.6 & \\
\hline \multirow[t]{2}{*}{ Financial capital } & Mean & 1575.3 & 1685.3 & \multirow[t]{2}{*}{0.580} \\
\hline & Std. dev. & 1570.5 & 1450.8 & \\
\hline
\end{tabular}

$* * *, * *$, and $*$ indicate significances at $1 \%, 5 \%$ and $10 \%$, respectively.

Source: from my survey

Average human capitals are not significantly difference among lowlands (11.2) and highlands (11.2) of studied areas (table 5). Figure 2 indicates how households intensity of income diversification goes with ownership of human capital and indicate the positive effect of human capital ownership on household intensity of income diversification. 


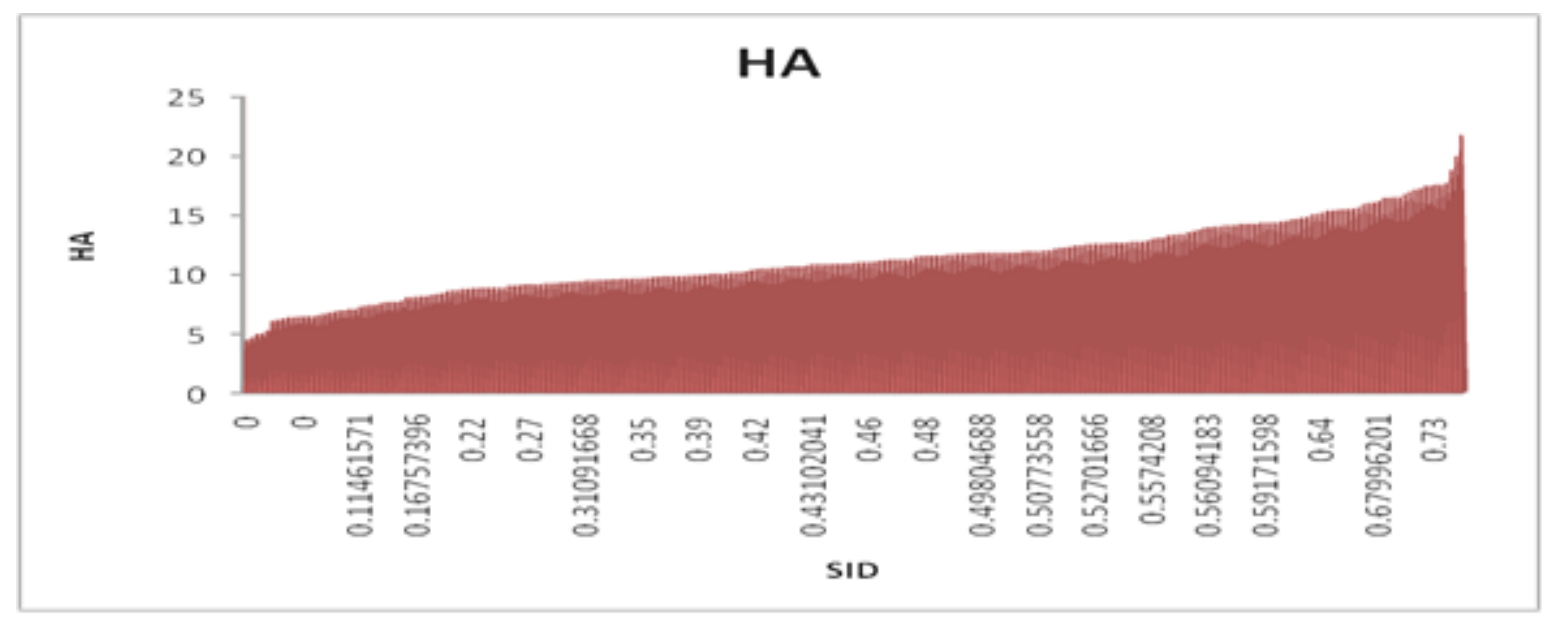

Figure 2: Linkage between human capital and income diversification $\mathrm{SID}=$ Simpson index of diversification, $\mathrm{HC}=$ Human Capital Source: own survey

Average financial capitals shows the similar distribution among lowlands (1575) and highlands (1685) of studied areas. Households whose owned more of financial capital were received more income from all non-farm activities than others. Figure 3 indicates how income diversification goes with ownership of financial capital and indicate the positive effect of financial capital ownership on household intensity of income diversification. In this case households whose degree of income diversification is less than $38 \%$ degree of diversification were not owned any financial capitals.

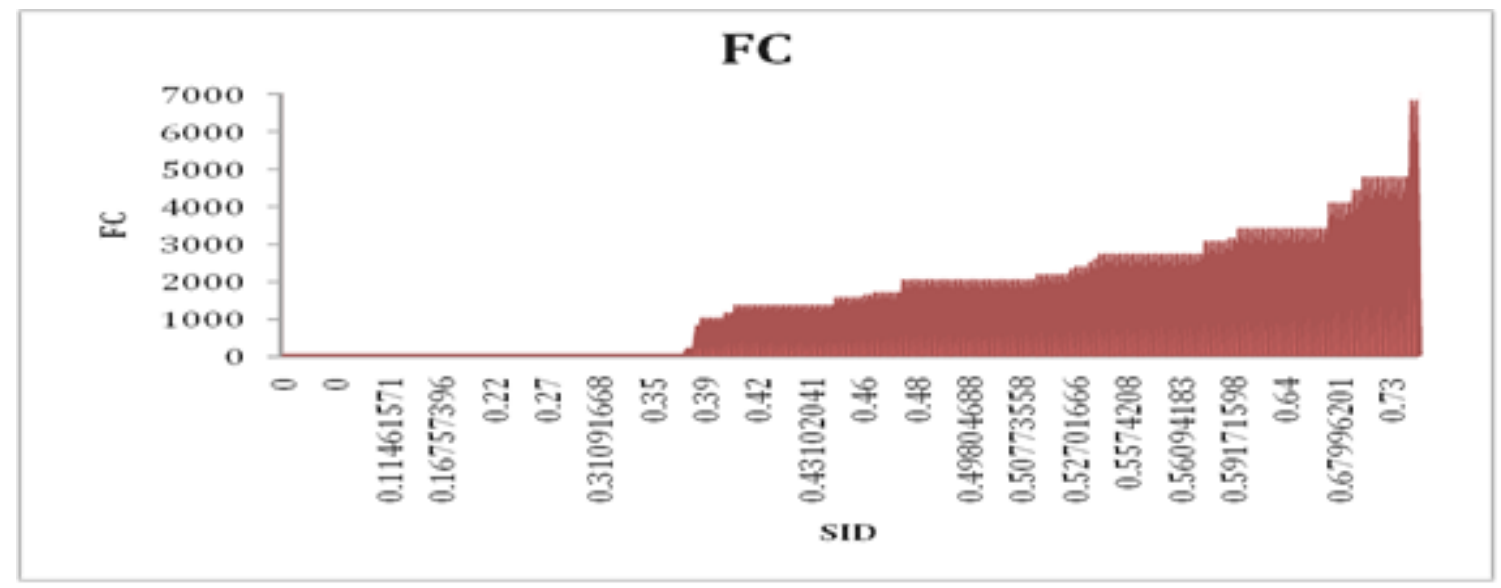

Figure 3: Linkage between financial capital and income diversification $\mathrm{SID}=$ Simpson index of diversification, $\mathrm{FC}=$ Financial Capital Source: own survey

\subsection{Determinants of Income Diversification}

The dependent variable is SID, which taking a value 0 to 1 . As indicated by the chi-square statistics, likelihood test ratio statistics is highly significant (sign. $=0.0000$ ) suggesting strong explanatory power of the model. 


\section{Sex}

The study result didn't confirm expected outcome and indicate that being female have positive and significant influence household's intensity of diversification at 5\% significance level $(\mathrm{p}=0.045)$. The result indicates that, male headed household most likely decreases the intensity of income diversification into different income source activities. A male headed household more depends on agricultural activities because of agricultural activities are labour intensive and rural households think agricultural activities as male oriented activities. Therefore, whatever they have enough farm lands female headed households prefer to participate in nonfarm activities. The result of the model also shows, when other factors is unchanged, the probability of households income diversification intensity were decrease by $2.3 \%$ as the $\mathrm{HH}$ headed by male. Opposite to this, being male has positive relationship with income diversification for the reason that in most developing countries females engaged in farm self employment [21].

\section{Human Capital}

Human capital has significant $(\mathrm{p}<0.006)$ and positive effect on households intensity of diversification. Keeping other factors constant; as households own one additional unit of human capital, household intensity of diversification (SID) increase by $0.7 \%$. This result confirms with previous expectation. This results indicates that those farmers endowed more of human capital were involve more in different nonfarm and farm income sources than those who own less human capital. This is due to most probably human capital (education attainment of $\mathrm{HHH}$, educated family member, Age and Access to different labor source) help them as base resources to decide to engage in different activities and households think human capital as a source of skill, experience, knowledge and labor force. This finding is in line with the finding of Amare and Belaineh, [22], and Devereux and Sussex, [23] of households' education is the base for equipping households with information which enable them to diversify their income sources.

Table 6:Tobit model result of determinants of household intensity of income diversification

\begin{tabular}{|c|c|c|c|c|c|}
\hline SID & Coef. & Marginal effect & $\begin{array}{l}\text { Robust } \\
\text { Std. Err. }\end{array}$ & $\mathbf{Z}$ & $|\mathbf{P}>| \mathbf{Z} \mid$ \\
\hline Sex & $-0.023 * *$ & 0.023 & 0.012 & -2.02 & 0.045 \\
\hline Fertilizer & -0.009 & 0.010 & 0.012 & -0.84 & 0.402 \\
\hline Improved Seed & -0.007 & 0.007 & 0.012 & -0.62 & 0.537 \\
\hline Irrigation & 0.010 & 0.010 & 0.013 & 0.81 & 0.417 \\
\hline Training & $-0.018^{*}$ & 0.019 & 0.010 & -1.91 & 0.057 \\
\hline Market distance & -0.001 & 0.0001 & 0.001 & -0.40 & 0.692 \\
\hline Extension Contact & $0.130 * * *$ & 0.130 & 0.007 & 19.29 & 0.000 \\
\hline Social leadership & 0.004 & 0.004 & 0.010 & 0.47 & 0.639 \\
\hline Cooperatives & $-0.030 * *$ & 0.031 & 0.015 & -2.08 & 0.039 \\
\hline Human capital & $0.007 * * *$ & 0.007 & 0.003 & 2.80 & 0.006 \\
\hline Physical capital & 0.0003 & 0.0003 & 0.0001 & 0.52 & 0.603 \\
\hline Financial capital & $0.0004 * * *$ & 0.0009 & 0.0001 & 2.60 & 0.010 \\
\hline Constant & 0.137 & & 0.035 & 3.95 & 0.000 \\
\hline /sigma & 0.069 & & 0.005 & & \\
\hline
\end{tabular}




\begin{tabular}{||lrr|}
\hline Tobit regression & Number of obs $=$ & 237 \\
& $\mathrm{~F}(12,225)=$ & 108.16 \\
Log pseudo likelihood $=263.16387$ & Prob $>\mathrm{F}$ & 0.0000 \\
& Pseudo $2 \quad=$ & -10.2760 \\
Obs. summary: & \\
& 237-total observations \\
& 12-left censored observations at SID $<=0$ \\
225-uncensored observations & 0-right-censored observations \\
\hline
\end{tabular}

$* * *, * *$, and $*$ indicate significances at $1 \%, 5 \%$ and $10 \%$, respectively.

Source: from my survey

\section{Financial Capital}

The study was founded ownership of financial asset affect the intensity of household income diversification positively and significantly at $1 \%$ significance level $(\mathrm{p}=0.01)$ and the result confirm to prior expectation. The marginal effect of this study shows keeping other factors unchanged; increasing in household financial capital ownership index by one unit increase a household's probability of income diversification intensity by $0.09 \%$. This shows that financial assets in rural areas used for financing other income generating activities outside agriculture or for purchase of agricultural input to increase the agricultural productivity. In other words household income diversification driven for accumulative motive and survival motive which is in contrary with the finding done by Dimova, [24], in Tanzania. Different author was done their studies on the effects of financial asset components on income diversification than its index. According to Bassie, [25], access to credit affect the level of income diversification of household's positively.

\section{Extension Contact}

Agricultural extension workers number of contact per month was influenced significantly and positively household intensity of income diversification at $1 \%$ significance level. Other factors keep constant, household income diversification intensity increased by $13 \%$ as extension contacts of household increased by one contact per month. The author has discussed with extension workers on type of service they deliver for farm households and they deliver services on agricultural production techniques, usefulness of new high yielding varieties and usage of yield increasing inputs, the farmers have been given an eye opener about the opportunities and possible sources of farm and nonfarm income around their area. The sign is confirm to our prior expectation and study done by Zerai and Gebreegziaber [26], of the aim of agricultural extension program is to induce rural households to diversify their income sources. Bernard et al., [27] shows number of household contacts per month during production period increases households degree of income diversification.

\section{Cooperatives Membership}

Household's cooperative membership has significant and negative correlation with household intensity of at $5 \%$ significant level $(\mathrm{p}=0.039)$. The result indicates that, other factor kept constant, probability of household income diversification intensity to different sources were decreased by $3.1 \%$ as a household member in cooperatives. The study was founded that those farmers who were member of cooperative were less likely participates in different income generating activities than those who were not member. The reverse is true for those households who didn't member of 
cooperative diversify their income more. The possible justification is that $\mathrm{HH}$ member in cooperatives most likely increases the production and productivity of agricultural activities; this can help farmer to get access to more food and generate more income so that they satisfy their family requirements from one or two source of income. Thus, households may not wonder searching for more activities. This result suggests that, households member in agricultural cooperatives help households decision to intensify agricultural activities than nonfarm activities [28].

\section{Access to Training}

The model result confirmed expected outcome and indicate that agricultural training have negatively and significantly affect household's level of income diversification at $10 \%$ significance level. The result of the model indicates, keeping other factors unchanged, the probability of households income diversification intensity were dropped by $1.9 \%$ as the farmers involve in agricultural training. This implies that households access to agricultural training most likely decreases the likelihood of income diversification into different income source activities. The probable reason is that the training given for household in the study area were mostly on agricultural productiveness which enhances agricultural production skills, knowledge and experiences of households. This situation helps farmers to get better production, and then this most likely leads to obtain more income to fulfill their family requirements. Those households most probably conduct this activity not accumulate wealth, but due to the lack of opportunities to choice the better options. Study done by Khatun and Roy [29] indicates that there was positive relationship between access to training given by agricultural extension workers and income diversification but negatively affected by training given on agricultural productivity in short run.

\section{Conclusion and Recommendations}

\subsection{Conclusion}

Agriculture is the dominant economic activity and the primary source of income for rural households in the study area. However, due to ownership of fragmented farm land and uncontrolled population growth, the agricultural production has been deteriorating over time and has forced people to look for alternative employment option other than agriculture. A significant number of rural households engage in different non-farm activities. The study concluded that nonfarm activities play insignificant roles in this study area contributing about $9.08 \%$ of the total household income. In terms of participation, about $43 \%$ of sample households participate in nonfarm activities. The results show that the contribution of non farm income to total household income is smaller compared to farm income despite the high level of participation in non-farm activities.

Households of Yayu woredas were rely on agricultural activity than of Hurumu woredas. With an increase in human capital, farmers tend to engage in agricultural production and non-agricultural activities to diversify source of household livelihood. Households those own more human capital and financial capital were rather focus on cash crop agricultural products and mostly participate in more non-farm activities those have more. 
However, with an increase in financial capital, farmers tend to engage in non-agricultural production and engage in outside enterprises in household sideline production as a way to supplement income and to achieve diversified income. The result of this study indicates that a low physical asset endowment was the main indicator of poor wealth groups. Less ownership of physical assets could not enable them to generate enough income from farm activities.

Households endowed more human capital assets participate more in different income sources than with less human capital owners. Financial capital and human capital has significant and positive influence on household intensity of income diversification. Access to fertilizer, sex of household head and access to training has significant and negative influence on household intensity of income diversification. Extension contact has a significant and positive effect on household intensity of income diversification. Generally, asset ownership is the basic factor for rural household income diversification and product specialization in the study area. Household gain different amounts of income based on their level asset endowed. Governmental and non-governmental actors should design a policy and strategy that could improve $\mathrm{HH}$ asset endowments and enable households access productive assets and capacity building programs and thereby improve the living standards in the area.

\section{References}

[1] Dercon, S., (2001). Assessing Vulnerability: Jesus College and CSAE, Department of Economics, Oxford University.

[2] Ellis, F., (2000). 'The Determinants of Rural Livelihood Diversification in Developing Countries: Journal of Agricultural Economics 51(2): 289-302.

[3] De Janvry, A., Fafchamps, M., and Sadoulet, E., (1991). Peasant household behavior with missing markets: some paradoxes explained, Economic Journal 101 (409): 1400-1417.

[4] Beyene, A., (2008). Determinants of off-farm participation decision of farm households in Ethiopia: Agrekon, Vol 47, No. 1

[5] World Bank Development Report. 2008. Agriculture for Development Washington, DC.

[6] Dercon, S., 2001. Assessing Vulnerability: Jesus College and CSAE, Department of Economics, Oxford University.

[7] Ellis, F., 2000. Rural Livelihoods and Diversity in Developing Countries: Oxford University Press.

[8] Barrett, C., and Reardon, T., 2000. Asset, Activity and Income Diversification among African Agriculturalists: Some Practical Issues, Availableat SSRN 257344."

[9] Mulat, D., 2001. Off-farm Income Generation Opportunities in Ethiopia; Opportunities and constraints in food insecure woredas of Oromia and Amhara Regional States. Ethiopian Development Forum. Volume 2. Number 1.

[10] Hoogeveen, J., 2001. Income Risk, Consumption Security and the Poor. Oxford Develop. Stud. 30(1):105-121.

[11] Damite, D., 2003. The Determinants and Impacts of Income Diversification in Rural Ethiopia: The Case of Communities in Southern Nations, Nationalities, and Peoples Regional State unpublished MSc Thesis, Graduate School of Economics, and Addis Ababa University, Ethiopia.

[12] Beyene, A., 2008. Determinants of off-farm participation decision of farm households in Ethiopia: Agrekon, Vol 47, No. 1

[13] Demissie, A., and Legesse,B., 2013. Determinants of income diversification among rural households the case of smallholder farmers in Fedis district, Eastern hararghe zone, Ethiopia: Journal of Development and Agricultural Economics Vol. 5(3), pp. 120-128.

[14] DFID., 1999. (Department for International Development) Sustainable Rural Livelihoods Guidance Sheet, London, UK. 
[15] Yamane, T. 1967. Statistics an Introductory Analysis, 2nd Ed, New York: Harper and Row.

[16] McKenzie, J., 2005. Measuring Inequality with Asset Indicators: Journal of Population Economics 18, no. 2: 229-60.

[17] Smith, R., A. Gordon, K. Meadows and Zwick, K., 2002. Livelihood diversification in Uganda: Patterns and determinants of change across two rural districts. In: Food Policy 26: 421-435.

[18] Minot, N., Epprecht, M., and T.T.T., and Trung Q., 2006. Income Diversification and Poverty in the Northern Uplands of Vietnam. IFPRI Research Report 145: 1-111. Washington, D.C.

[19] Joshi, P., Gulati, A., Birthal, S., and Twari, L., 2003. Agriculture diversification in South Asia: Pattern, Determinants and Policy Implications. Discussion Paper No. 57. Market Structure studies Divison, International Food Policy Research Institute, Washington, D.C.

[20] Greene, H., 2003. Econometric Analysis: Fourth Edition. New York University Macmillan Publishing Company.

[21] Block, S., and Webb, P., 2001. The Dynamics of Livelihood Diversification in Post Famine Ethiopia: Food Policy, 26(4):333-350.

[22] Amare, D., and Belaineh L., 2013. Determinants of income diversification among rural households: The case of smallholder farmers in Fedis district, Eastern hararghe zone, Ethiopia: Journal of Development and Agricultural Economics Vol. 5(3), pp. 120-128.

[23] Devereux and Sussex., 2000. Social safety nets for poverty alleviation in southern Africa: A Research Report for the Department for International Development ESCOR,' Report" R7017.

[24] Dimova, R. and Sen, K., 2010. Household Income Diversification a Means of Survival or a Means of Accumulation? Panel Data Evidence from Tanzania, Working Paper No.122.

[25] Bassie, Y., 2014. Determinants of Household Income Diversification and Its Effect on Food Security Status in Rural Ethiopia: Evidence from Ethiopia Longitudinal Rural Household.

[26] Zerai, B., and Gebreegziabher, Z., 2011. Effect of Non-farm Income on Household Food Security in Eastern Tigrai, Ethiopia: An Entitlement Approach. Food Science and Quality Management, Vol 1.

[27] Bernard A., Agyeman S., Samuel A., and Edward E., 2014. Determinants of Income Diversification of Farm Households in the Western Region of Ghana: Quarterly Journal of International Agriculture 53 (2014), No. 1.

[28] Conley, G., and Udry, R., 2010. Learning about a new technology in Pineapple in Ghana: The American Economic Review, 100(1), 35-69.

[29] Dilruba, K., and Roy, B., 2012. Rural livelihood diversification in West Bengal: Determinants and Constraints. Agricultural Economics Research Review Vol.25(No.1) January-June 2012 pp 115124.

\footnotetext{
*Corresponding author.

E-mail address: drpkdara@gmail.com
} 